\title{
Loancorhynchus catrillancai gen. et sp. nov., a new swordfish (Xiphioidei, Blochiidae) from the Middle Eocene of central Chile
}

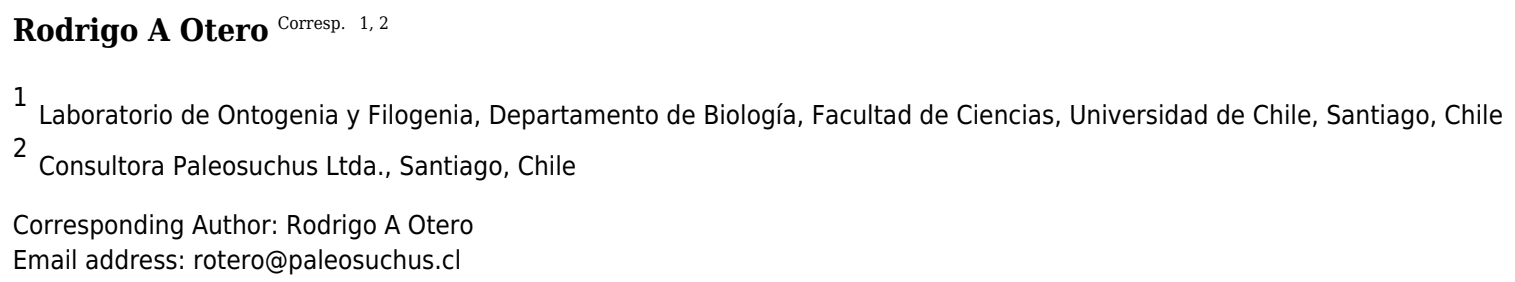

This contribution describes the skull remains of a swordfish (Perciformes, Xiphioidei), recovered from Middle Eocene beds of central Chile. Comparison with known fossil and extant xiphioids reveals derived traits only present in the Neogene swordfish Xiphias gladius (Xiphiidae, Xiphiinae), these being a elongated rostrum composed of premaxillaries and possible prenasals, a dorsoventrally high and slender hyomandibular-metapterygoid complex, and a rounded, convex operculum. Also, strong ridges and sulci are present in the dorsal part of the rostrum, a feature only present in the billfish genera Aglyptorhynchus and Xiphiorhynchus, and in the swordfish genus Blochius. In addition, the specimen also has villiform teeth in the rostrum and lower jaw, a feature previously documented only in the Paleocene genus Hemingwaya. Such a unique combination of characters in the specimen allows classifying it as a new genus and species, Loancorhynchus catrillancai. Phylogenetic analyses obtained Xiphiorhynchus outside the Xiphiidae, suggesting instead narrow relationships to the Paleocene-Eocene genera Hemingwaya + Palaeorhynchus + Homorhynchus. Loancorhynchus is obtained as an intermediate form between Xiphias and Blochius. The specimen represents the first Paleogene swordfish described in the southeastern Pacific. 
1 Loancorhynchus catrillancai gen. et sp. nov., a new swordfish (Xiphioidei,

2 Blochiidae) from the Middle Eocene of central Chile

3

4 Rodrigo A. Otero ${ }^{1,2}$

5

$6{ }^{1}$ Laboratorio de Ontogenia y Filogenia, Departamento de Biología, Facultad de Ciencias,

7 Universidad de Chile., Santiago, Chile

$8{ }^{2}$ Consultora Paleosuchus Ltda., Santiago, Chile

9

10 Corresponding author:

11 Rodrigo Otero

12 otero2112@gmail.com

13

$14-$ 


\section{ABSTRACT}

16 This contribution describes the skull remains of a swordfish (Perciformes, Xiphioidei), recovered

17 from Middle Eocene beds of central Chile. Comparison with known fossil and extant xiphioids

18 reveals derived traits only present in the Neogene swordfish Xiphias gladius (Xiphiidae,

19 Xiphiinae), these being a elongated rostrum composed of premaxillaries and possible prenasals, a

20 dorsoventrally high and slender hyomandibular-metapterygoid complex, and a rounded, convex

21 operculum. Also, strong ridges and sulci are present in the dorsal part of the rostrum, a feature

22 only present in the billfish genera Aglyptorhynchus and Xiphiorhynchus, and in the swordfish

23 genus Blochius. In addition, the specimen also has villiform teeth in the rostrum and lower jaw, a

24 feature previously documented only in the Paleocene genus Hemingwaya. Such a unique

25 combination of characters in the specimen allows classifying it as a new genus and species,

26 Loancorhynchus catrillancai. Phylogenetic analyses obtained Xiphiorhynchus outside the

27 Xiphiidae, suggesting instead narrow relationships to the Paleocene-Eocene genera Hemingwaya

28 + Palaeorhynchus + Homorhynchus. Loancorhynchus is obtained as an intermediate form

29 between Xiphias and Blochius. The specimen represents the first Paleogene swordfish described

30 in the southeastern Pacific.

\section{INTRODUCTION}

33 The Xiphioidei (Osteichthyes, Perciformes) is a group of fishes considered to be monophyletic,

34 being characterized by elongated premaxillaries forming a rigid rostrum, and by having villiform

35 teeth (Fierstine, 2006), although the latter can be secondarily lost during the ontogeny of some

36 taxa (e.g., Xiphias gladius). To date, five family-level groups are known: Hemingwayidae,

37 Palaeorhynchidae, Blochiidae, Xiphiidae and Istiophoridae (Fierstine, 2006; Gottfried et al., 
38 2013). The two latter clades, Xiphiidae and Istiophoridae, are the only lineages with extant

39 representatives.

40 Late Cretaceous-Paleogene records of xiphioids are scarce and restricted to the

41 Weddellian Province. Zinsmeister (1979) defined it as a large province including southern South

42 America, Antarctica, New Zealand and part of Australia, isolated between the Late

43 Cretaceous-Paleogene by the geography of Gondwana landmass and prevailing oceanic

44 circulation, resulting in the development of highly endemic marine faunas (Zinsmeister, 1982).

45 The first mention of a Paleogene Xiphioidei from the Weddellian Province concerns a large,

46 isolated vertebra from lower Eocene levels of La Meseta Formation, in Marambio (=Seymour)

47 Island, Antarctica, referred to cf. Xiphiorhynchus (Cione et al., 2001). Friedman and Otero

48 (2009) added to this record the preliminary description of a fragmentary rostrum and dentaries

49 referred to as Xiphiorhynchine indet., which was recovered from Paleogene levels of central

50 Chile. This material is part of the same specimen described here. After that, Gottfried et al.

51 (2013) described a new species of palaeorhynchid, Aglyptorynchus hakataramea, from late

52 Oligocene levels exposed in South Canterbury, South Island, New Zealand. A fourth specimen

53 (GS 13924; GNS Science, Lower Hutt, New Zealand), still awaiting description, belongs to an

54 articulated skull embedded in a concretion, recovered from Eocene levels of Hampden Beach,

55 Otago, South Island, New Zealand (Campbell et al., 2013). Locally, Neogene records of xiphiids

56 and istiophorids are well-known in the Miocene-Pliocene of Chile (Long, 1993; Walsh, 2001;

57 Pyenson et al., 2014). A mention of cf. Xiphiorhynchus from the Miocene-Pliocene of Peru was

58 provided by Muizon and DeVries (1985), but the material was not figured neither a repository

59 was provided. 
This contribution describes the only xiphioid recovered to date from Paleogene beds of

61 the southeastern Pacific. After further preparation, new skull elements are added to its first

62 preliminary description by Friedman and Otero (2009). In addition, the stratigraphic provenance

63 of the specimen is clarified here. As a result, a new genus and species are here proposed. The

64 fossil is found to be Middle Eocene in age, representing the first significantly diagnostic

65 specimen from the Paleogene of South America, and adding to the knowledge of the sparse

66 Paleogene xiphioids known along the Southern Hemisphere.

67

\section{LOCALITY AND GEOLOGIC SETTING}

Loanco is a small cove placed $350 \mathrm{~km}$ south from Santiago (Fig. 1A). In this locality, rich

fossiliferous marine rocks crop out along the coastal cliffs and the intertidal surface. Beds exposed north of Loanco have been recognized as equivalent to the Late Cretaceous Quiriquina Formation (Tavera, 1987), assigned to the upper Maastrichtian based on biostratigraphy and stratigraphic correlations (Otero, 2015; Castro et al., 2016). A second sedimentary and also marine unit was recently found cropping out south of Loanco. From the latter, Suárez and Otero (2008) recovered associated teeth, vertebrae and mandibular cartilague belonging to a single individual referred to the genus Isurolamna (Chondrichthyes, Elasmobranchii). Previous geologic studies have referred the outcrops in south of Loanco as Late Cretaceous in age (Sernageomin, 2003). During 2012, new fieldwork in this locality has provided material referable to the nautiloid genus Aturia (Zambrano et al., 2014) and Imaizula araucana

80 (recovered during fieldwork of this research), which are unequivocally Cenozoic taxa. More

81 recently, Otero (2015) identified the presence of chondrichthyan teeth referable to

82 Macrorhizodus praecursor (SGO.PV.6633; SGO, Paleontología de Vertebrados, Museo 
83 Nacional de Historia Natural, Santiago, Chile). The combined biochron of this assemblage

84 indicates a Middle Eocene age for the fossil-bearing levels.

85 The Quiriquina Formation and the Paleogene marine units of central Chile were deposited

86 in a continental shelf which is part of a single realm known as the Arauco Basin (Mordojovic,

87 1981), extended at least between $33^{\circ}$ to $37^{\circ} \mathrm{S}$. In this context, Paleogene units have been

88 recorded along the whole basin, being deposited in angular unconformity over Late Cretaceous

89 beds of the Quiriquina Formation or equivalent units. In Cocholgüe and the Quiriquina Island,

$90120 \mathrm{~km}$ south from Loanco, the Quiriquina Formation is unconformably overlain by Paleogene

91 sediments of the Concepción Group (sensu Charrier et al., 2007; =Lebu Group in Cecioni, 1968;

92 Le Roux et al., 2008). Several Paleogene units have been characterized in the Arauco Basin,

93 representing different stages of a transgressive-regressive cycle. After a Paleocene hiatus, from

94 base to roof, a first shallow transgression is represented by the marine-to-continental, upper

95 Paleogene-lower Eocene Pilpilco Formation (Muñoz-Cristi, 1968), conformed by ca. $150 \mathrm{~m}$ of

96 fine-grained, greenish sandstones with clay intercalations. The unit unconformably overlies the

97 metamorphic basement and the Quiriquina Formation. The Pilpilco Formation is covered by a

98 conformably deposited, regressive unit represented by the continental, coal-rich sandstones of

99 the Curanilahue Formation (Tavera, 1942; Martinez-Pardo, 1968a) assigned to the lower

100 Eocene. Over the latter and in conformable contact lays the Boca Lebu Formation (Muñoz-Cristi,

$1011946 ; 1968)$, which comprises a variable section between 250 to $600 \mathrm{~m}$ of marine, fossiliferous

102 green sandstones with glauconite. The upper regression is represented by the continental

103 Trihueco Formation (Muñoz-Cristi, 1946; 1968) comprised by 3 to $10 \mathrm{~m}$ thick banks with blue-

104 to-grey sandstones with intercalations of brown, coal-rich shales and coal seams. The final

105 transgression is represented by the Millongue Formation (Muñoz-Cristi, 1946). This unit was 
106 characterized by García (1968) as $270 \mathrm{~m}$ of thin beds of shales and limestones with leaf prints

107 and frequent fragments of carbonized wood, representing a marine-continental environment.

108 Following this geologic scheme (Fig. 1B), the fossil-bearing section studied here could be

109 referred to one of these marine units (i.e., basal Pilpilco Formation; Boca Lebu Formation or

110 Millongue Formation).

111 The studied section (Fig. 1C) is comprised from base to roof, by: $3 \mathrm{~m}$ of greenish

112 sandstones with banks of serpulids; $0.5 \mathrm{~m}$ with no outcrop; $2 \mathrm{~m}$ of reddish sandstones; $2 \mathrm{~m}$ with

113 no outcrop; $1.8 \mathrm{~m}$ of mid-grained sandstone, brown, with micaceous fragments, and having a

114 basal fine conglomerate. Fossils include teeth of Macrorhizodus praecursor, a phragmocone of

115 the nautiloid Aturia sp. (SGO.PI.6776), and an articulated individual of Imaizula araucana; 14.3

$116 \mathrm{~m}$ of mid-grained, yellow-to-green sandstone with lenses including banks of terebratulid

117 brachiopods. Isolated terebratulids, pectinids and carbonized wood fragments occur near the roof

118 of the level; $6 \mathrm{~m}$ of mid-grained, reddish to brown sandstones, including few individuals of the

119 bivalvian Pinna sp. in life position, as well as an isolated lamniform vertebra, serpulids,

120 carbonized wood fragments, and Teredolites isp. Lithologically, these strata could be referred to

121 the Boca Lebu or Millongue formations; however, the presence of Pinna sp. has been previously

122 considered as a proxy for distinguishing both units, because the occurrence of this genus seems

123 to be restricted only to the Millongue Formation (Martínez-Pardo, 1968b: p. 100). Adding to

124 these facts, a Middle Eocene age is proposed based on the combined biochron of the faunal

125 assemblage. Then, the studied unit is here proposed to be equivalent to the Millongue Formation.

126 Several outcrops of the same unit in south Loanco were documented by the author during the

127 extraction of SGO.PV.6635 (associated chondrichthyan remains referred to Isurolamna sp.);

128 however, these were later covered by sand banks after the large earthquake and subsequent 
129 tsunami of central Chile in February 27, 2010. Currently, the unit is only visible during low tides

130 along the coastal line south from Loanco, but its extension under the recent sands reaches

131 hundreds of meters. The sediment attached to SGO.PV.6634 is remarkably similar to the fossil-

132 bearing level including Aturia sp. and Imaizula araucana; however, the lack of historical

133 information regarding its collection (see text below) makes impossible to assure a precise

134 stratigraphic provenance.

136 MATERIAL AND METHODS

Historical background of the studied specimen-SGO.PV.6634 (Fig. 2) was recovered

by H. Fuenzalida, former director of the Museo Nacional de Historia Natural (MNHN, National

Museum of Natural History, Santiago, Chile), during 1935 from rocks exposed south of Loanco,

140 as is accounted by his personal field notes archived in the aforementioned institution. The

141 collected material also included ammonoids, bivalvians and plesiosaur remains; however, these

142 were recovered without stratigraphic data. Later, the collection of Fuenzalida was studied by San

143 Martín (1946), who assigned a 'Senonian' age to the assemblage based on ammonoids, and

144 recognizing affinities with the fauna of the Quiriquina Formation. Among the determinations by

145 San Martín (1946), the plesiosaur remains were considered as Cenozoic remains of

146 indeterminate cetaceans. The swordfish remains were not prepared at that moment, being

147 interpreted as Teredo remains. Since then, the whole collection was housed in the MNHN.

148 Probably because of its antiquity, the collection was not included in any catalog, being re-

149 discovered during 2008 by S. Soto-Acuña (Universidad de Chile). After this, a first inspection of

150 the 'wood remains' revealed that they are actually bone remains. Subsequently, part of the

151 material was mechanically prepared by the author during 2008 and 2009. The rostrum and 
152 dentaries were preliminary presented and identified as an indeterminate xiphiorhynchine by

153 Friedman and Otero (2009). These authors also gave to the specimen, for the first time, a formal

154 numeration and repository (SGO.PV.6634). Further preparation was carried out by the author

155 during 2012 and 2013, uncovering new elements of the skull. Anatomical identifications were

156 made during April, 2013 by direct comparison with the holotype of Aglyptorhynchus

157 hakataramea Gottfried et al. 2013, housed in the Department of Geology of the Otago

158 University, Dunedin, New Zealand. Further anatomical identifications follow the classical work

159 of Gregory and Conrad (1937). Considering the osteological nomenclature of billfishes in general,

160 there is a controversial issue regarding the presence of prenasal bone (Shultz, 1987; Fierstine,

161 1990; Fierstine and Voigt 1996). Resolving this issue is out of the scope of this contribution.

162 However, this research follows the uncertain denomination of the dorsomedial rostrum element

163 in question as prenasals, as was done by Fierstine (1990). The same element was considered by

164 Gregory and Conrad (1937) as the nasal.

165 Phylogenetic analysis-Phylogenetic analysis used a modified version of the datamatrix

166 with twelve taxa (fossil and extant) and 25 characters provided by Fierstine and Monsch (2002).

167 Modifications here introduced include three new characters (26 to 28) and addition of new states

168 for characters 4, 11 and 15 (see Suplementary Data). Original dataset of Istiophoridae was

169 replaced with the scorings of Istiophorus albicans and Makaira nigricans (taken from

170 Nakamura, 1985). Original dataset of Aglyptorhynchus was also replaced with the scores of

171 Aglyptorhynchus hatakaramea, which is a fairly complete specimen from the Eocene of New

172 Zealand (Gottfried et al., 2013). Also, the scores of Hemingwaya sarissa Sytchevskaya and

173 Prokofiev, 2002; and SGO.PV.6634 were added to the datamatrix. Few taxa in the original

174 datamatrix of Fierstine and Monsch (2002) were pruned based in different criteria: 
175 Cylindracanthus - This genus lacks a subdermal tooth base attachment (Grandstaff et al.,

176 2017), leading to the conclusion that Cylindracanthus does not belong to any billfish

177 (=Xiphioidei), which indeed have subdermal tooth base attachments. Previously, Parris and

178 Grandstaff (2001) suggested that Cylindracanthus could be related to Acipenseriformes.

179 Hemirhabdorhynchus_Fierstine and Monsch (2002) originally excluded this genus from

180 phylogenetic analysis based in its ambiguity. This observation is here followed. Even more, no

181 further clarification regarding the anatomy and taxonomy of Hemirhabdorhynchus was provided

182 since Shultz (1987). Fierstine and Monsch (2002) mentioned Shultz (1987) as the source of

183 information used by them for scoring of this genus.

184 'Blochius' moorheadi-This was detected as an unstable taxon with the IterPcr Script

185 (Pol and Escapa, 2009). Fierstine and Monsch (2002) also found this taxon as unstable, pruning

186 it from the returned reduced consensus tree (Fierstine and Monsch, 2002: fig. 7).

187 Pseudotetrapturus luteus - This taxon was removed for reducing ambiguity. Besides the

188 rostrum, the skull of the holotype is naturally crushed, and the postcranial skeleton is currently

189 lost (Monsch and Bannikov, 2011).

190 The modified datamatrix includes 11 taxa and 28 characters. This was analyzed with TNT

191 software (Goloboff et al., 2008).

192 Permissions - The studied fossil was collected in 1935. At that time, field permissions

193 for paleontologic excavation in Chile were not required. Futher fieldwork in 2012 was granted

194 by the Chilean authority in charge, Consejo de Monumentos Nacionales, in document Ord. CMN

$195 \mathrm{~N}^{\circ} 2962 / 2009$ and currently, in Ord. CMN N 3793/2014.

196 Nomenclatural acts-New names contained in the electronic version of this article are

197 effectively published under the International Commission on Zoological Nomenclature (ICZN) 
198 from the electronic edition alone. This published work and the nomenclatural acts it contains

199 have been registered in ZooBank, the online registration system for the ICZN. The ZooBank

200 LSIDs (Life Science Identifiers) can be resolved and the associated information viewed through

201 any standard web browser by appending the LSID to the prefix "http://zoobank.org/". The LSID

202 for this publication are:

203 Genus name: LSID:urn:lsid:zoobank.org:act:FA566753-31D4-45B5-9E7A-03F8C7526E7D

204 Species name: LSID: urn:1sid:zoobank.org:act:8FFA9EE9-A81B-4468-9FBA-9D6C306D86C8

205 Publication: LSID:urn:Isid:zoobank.org:pub:ED22325A-7C78-469A-9985-365C31064652

206

207 The electronic version of this article in Portable Document Format (PDF) will represent a

208 published work according to the International Commission on Zoological Nomenclature (ICZN),

209 and hence the new names contained in the electronic version are effectively published under that

210 Code from the electronic edition alone. This published work and the nomenclatural acts it

211 contains have been registered in ZooBank, the online registration system for the ICZN. The

212 ZooBank LSIDs (Life Science Identifiers) can be resolved and the associated information viewed

213 through any standard web browser by appending the LSID to the prefix http://zoobank.org/. The

214 LSID for this publication is: LSID:urn:1sid:zoobank.org:pub:ED22325A-7C78-469A-9985-

$215 \quad 365 C 31064652$

216 The online version of this work is archived and available from the following digital

217 repositories: PeerJ, PubMed Central and CLOCKSS.

218

219 SYSTEMATIC PALEONTOLOGY

220 
221 Order PERCIFORMES sensu Johnson and Patterson, 1993

222 Suborder XIPHIOIDEI sensu Gosline, 1968

223 Family BLOCHIIDAE (Bleeker, 1859)

224

225 Genus LOANCORHYNCHUS nov.

226

227

228

229

230

231

232

233

234

235

236

237

238

239 240 bones.

241

242

243

Type Species—Loancorhynchus catrillancai gen. et sp. nov., by monotypy.

Derivation of Name - Genus name after its type locality, Loanco, Región del Maule, central Chile.

Diagnosis - As for the single known species, below.

LOANCORHYNCHUS CATRILLANCAI gen. et sp. nov.

(Fig. 2-6)

Teredo sp.: San Martín, 1946: p. 46.

Xiphiorhynchinae indet.: In Friedman and Otero, 2009.

Holotype-SGO.PV.6634, a dissarticulated three-dimensional skull preserving most of the rostrum (premaxillaries and prenasals?), fragments of both dentaries, a fragment of the left maxilla, left frontal, left metapterygoid+hyomandibular, both operculi, and several branchystegal

Derivation of Name - Honoring the memory of the Mapuche leader Camilo Catrillanca. Locality, Horizon and Age — Loanco, Región del Maule. Indeterminate levels of the Millongue Formation cropping out south Loanco. Middle Eocene. 
Diagnosis-Rostrum much longer than the dentaries, with villiform teeth reaching the

245 posterior part of the rostrum; rostrum and dentaries with villiform teeth over their occlusal and

246 latero-occlusal surface; rostrum with clearly oval, dorsally compressed cross-section,

247 intermediate between Xiphias and Xiphiorhynchus; operculum rounder and broader than in

248 Blochius longirostris but dorsoventrally more compressed than in Xiphias gladius;

249 hyomandibular/metaethmoid complex more gracile than in Blochius but broader than in Xiphias.

250 Other distinguishing characters-Loancorhynchus catrillancai skull has premaxillaries

251 joined into a pointed rostrum and a rostrum usually longer than the lower jaw. Both features have

252 been considered as diagnostic of the family Blochiidae by Fierstine and Monsch (2002). Unique

253 combination of characters include features found in Hemingwayidae (Sytchevskaya and

254 Prokofiev, 2002), Xiphiorhynchinae (Regan, 1909), Xiphiinae (sensu Fierstine, 2006) and

255 Blochiidae (Bleeker, 1859) Loancorhynchus catrillancai possesses villiform teeth along the

256 premaxillaries and also in the occusal surface of the dentaries. Such feature is only documented

257 in the Hemingwaya sarissa Sytchevskaya and Prokofiev, 2002. Loancorhynchus catrillancai also

258 possesses a thick, dorsoventrally compressed rostrum formed mostly by premaxillaries extended

259 posteriorly on each side, while its dorsal midline is conformed by an anterior extension of the

260 prenasals(?), and posteriorly, by a short extension of the dermethmoid, as it occurs in Xiphias; It

261 also shares with Xiphias the presence of a metapterygoid fused to the hymandibular, forming a

262 dorsoventrally high complex with a prominent dorsal articulation, and a subrounded, laterally

263 convex operculum (Gregory and Conrad, 1937). Traits shared with Xiphiorhynchinae include a

264 lower jaw shorter than the rostrum but comparatively larger than that of Xiphias; posterior part of

265 the rostrum with strong folds and sulci, as those present in Aglyptorhynchus, Xiphiorhynchus and 
266 Blochius; additional traits include a lower jaw with dentaries contacted in a large craniocaudal

267 symphysis as that present in Pseudotetrapturus, Blochius and all xiphiids.

268 Taxonomic placement of Loancorhynchus catrillancai - The phylogenetic analysis

269 (see Discussion below) confirms the placement of Blochiidae as the sister taxon of Xiphias

270 gladius (i.e., Xiphiidae), as previously obtained by Fierstine and Monsch (2002) and by

271 Fierstine (2006). Loancorhynchus catrillancai has a set of derived traits shared with Xiphias,

272 including a rostrum formed by premaxillaries + prenasals(?), a dorsoventrally high metapterygoid-

273 hyomandibular complex, and a large, rounded and convex operculum. On the other hand, the

274 presence of dorsal rostral ridges and sulci seems to be a symplesiomorphic trait shared with

275 Blochius spp. These characters support Loancorhynchus catrillancai within the node including

276 Xiphias + Blochius spp.; it is also segregated from other lineages with dorsal ridges (but having

277 more basal features), such as Aglyptorhynchus and Xiphiorhynchus. Finally, the presence of

278 villiform teeth over the occlusal surface of the dentaries is remarkable. Such a feature was

279 previously described only in hemingwayids (i.e., Hemingwaya sarissa Sytchevskaya and

280 Prokofiev, 2002). The presence of villiform teeth in Loancorhynchus catrillancai dentaries could

281 be atavic, or else, it could suggest a non-adult ontogenetic stage, as it occurs in the larval rostrum

282 of Xiphias that bears villiform teeth, but these are absent in its adult stage (Nakamura, 1985;

283 Johnson, 1986; Fierstine and Monsch, 2002). However, the latter hypothesis is unprobably for a

284 large specimen such as Loancorhynchus catrillancai, with a length estimated in $2.7 \mathrm{~m}$ (see

285 further text).

286

287 DESCRIPTION OF LOANCORHYNCHUS CATRILLANCAI HOLOTYPE 
General remarks - Loancorhynchus catrillancai is three-dimensionally preserved.

289 Besides the rostrum, all the available postorbital elements are well-preserved and none of them is

290 severely deformed. Both operculi even preserve their convexity. The rostrum is partially crushed

291 dorsoventrally. Its anteriormost fragment is slightly recurved to the right side. On the contrary,

292 the left dentary (the most complete) is recurved to the left side, which indicates that both

293 deformations were caused likely by taphonomic condition instead of occurring in the living

294 animal. During its preparation, it was evident that the skull was naturally dissarticulated and

295 embedded in a soft, reddish, micaceous sandstone (consistent with those observed in the base of

296 the studied section; see Geologic Setting). The length of the cranial elements in anatomic

297 position, represents approx. $60 \mathrm{~cm}$. Based on the affinities of Loancorhynchus catrillancai with

298 Blochiidae, the skull could reach a conservative length of $90 \mathrm{~cm}$, assuming a rostrum with a

299 blunt tip instead a gradually reduced, sharp tip. The body length of Loancorhynchus catrillancai

300 can be estimated based on the proportions of complete skeletons of Blochius longirostris, where

301 the skull is ca. one third of the whole skeleton (Fierstine and Monsch, 2002: fig. 1). Then,

302 Loancorhynchus catrillancai body length can be estimated in 2.7 meters.

303 Premaxillaries-The premaxillaries form most of the anteriormost part of the

304 rostrum.The anterior tip of the rostrum is lost; however, this was likely formed by the union of

305 both premaxillaries, suggested by their large participation in the anteriormost available rostrum

306 fragment. In the latter, premaxillaries are strongly fused in the mid and ventral part, being

307 interrupted in the dorsal midline by a thin anterior extension of the prenasals(?). Both fused

308 premaxillaries show a dorsoventrally compressed oval cross-section. Nutrient canali are not

309 obseved, probably due to taphonomic conditions. Profuse villiform teeth cover all the ventral and

310 lateral surface of both premaxillaries, over the whole length of the preserved rostrum (Fig. 3A, 
311 B). The posterior end of each premaxillary bears profuse craniocaudal striations. Two main

312 interior canali are visible in the anterior fragment of the rostrum (Fig. 3E,F, G). Smaller canali

313 are also present, being paired with respect to the rostrum midline.

314 Maxillaries-A small fragment of the left maxillary is preserved (Fig. 4). This lies

315 crushed under the left premaxillary. This bone is elongated with a sub-squared cross-section.

316 Based on the available fragment, the lateral exposure of each maxillary seems to be precluded by

317 the posterior extension of the premaxillaries.

318 Prenasals(?) - In the anteriormost available rostrum fragment, two thin bones in its

319 dorsal midline ar here interpreted as both prenasals(?) sensu Fierstine (1990) (Fig. 4). In cross-

320 section, their contact with the premaxillaries is obscured due to preservation. The posteriormost

321 available rostrum fragment preserves the posterior part of both prenasals(?).These laterally

322 diverge and they have a posterolateral notch (Fig. 4D), which marks the anterior margin of the

323 orbit. Then, the anteroventral orbit is laterally conformed by the posterior extension of the

324 premaxillary, and ventrally, by the posterior extension of the maxillary. The posterior end of

325 both prenasals(?) have strong folds and sulci over their dorsal surface.

326 Dermethmoid - In the posterior part of the rostrum, a partially open sutural contact is

327 visible asides the dorsal midline. This marks the contact of the prenasals(?) with the

328 dermethmoid, which is placed in the midline and tapers anteriorly. Dorsally, the dermethmoid

329 bears strong folds and sulci (Fig. 4). Its posterior part is missing.

330 Hyomandibular-Only the left hyomandibular is available. This element is complete

331 and well preserved (Fig. 5A-D). In lateral (external) view, this shows a prominent pterotic facet

332 which is medially recurved. In the same view, the sphenotic facet is high and diverged from the

333 pterotic facet under ca. $90^{\circ}$. A large opercular process is extended over the posterior margin of 
334 the hyomandibular. In posterior view, this process appears as diagonally oriented with respect to

335 the vertical. Over the lateral (external) surface, the hyomandibular bears a dorsoventral scar,

336 consistent with the preopercular groove. In both anterior and internal views, there is a large

337 foramen under the pterotic facet, here interpreted as the foramen for the truncus

338 hyoideomandibularis of the facial nerve (VII).

339 Metapterygoid-This bone remains strongly articulated to the hyomandibular (Fig. 5A-

340 D), although, its suture is still visible from the internal and lateral views. This element diagonally

341 overlaps the hyomndibular. Laterally, it contacts with the latter through a suture adjacent to the

342 preopercular groove. In internal view, the dorsal part of the metapterygoid is comparatively

343 broader than its external exposure. Its ventral margin has a squared outline.

344 Frontal-The left frontal is preserved (Fig. 5E, F), having the medial and posterior

345 margins missing. This element has a posterorlateral process. This indicates that the skull

346 becomes laterally broader immediately behind the orbit. In ventral (internal) view, the frontal

347 shows a thick ridge that broadens posteriorly.

348 Operculum-Only the left operculum is preserved (Fig. 5G) This shows the articular

349 process for the hyomandibular. It has a well-marked convexity immediately ventral to the

350 articulation.

351 Subopercular-Only the right subopercular is preserved (Fig. $5 \mathrm{H}$ ). This seems to be

352 complete. It has a dorsal rounded contour. This element remains articulated to the right

353 interopercular.

354 interopercular-It is crushed together with the subopercular due to taphonomic

355 conditions, but it can be distinguished as a bony element separated from the subopercular (Fig.

$3565 \mathrm{H})$. It has a triangular outline with a convex posterior margin. 
Dentaries-Fragments of both dentaries are preserved (Fig. 6). The left dentary is the

358

359

360

361

362

363

364

365

366

367

368

369

370

371

372

373

374

375

376

377

378

379

most complete. However, its anterior part as well as its posterior end are both missing. The right

dentary is represented by two separated fragments. The complete occlusal and laterodorsal

surface of the left dentary are covered by profuse, small villiform teeth. Villiform teeth are also

present in the two fragments of the right dentary. The left dentary is very straight, having a slight

lateral divergence in its posteriormost preserved end. Two separated fragments of the right

dentary can be attached to the left dentary in anatomic position. This shows that the jaw had a

large symphysis. The anterior cross-section of the preserved jaw has a sub-squared outline. The

anterior part of both dentaries narrows anteriorly. This suggests that the length of the missing

anterior part could be approximately $5 \mathrm{~cm}$. Both mandibular rami diverge posteriorly. Based on

this divergence, a temptative position of the jaw elements with respect to the rostrum can be

estimated. Even if this is not accurate, it is clear that the lower jaw is much shorter than the

rostrum.

Fin rays-Remains of least nine fin rays were recovered. All of them were included in a single block. A large incomplete fragment has an articular head, recurved with respect to the shaft. It also has a small bulk in its anterior margin. These features are present in the first pectoral ray of Xiphias gladius, reason by why it is identified as the latter element.

\section{DISCUSSION}

Historical background in billfish phylogeny_-The fossil billfish record was extensively reviewed by Fierstine (1972), recognizing five families (Blochiidae, Istiophoridae, Palaeorhynchidae, Xiphiidae and Xiphiorhynchidae). To these, Schultz (1987) added a sixth family, Tetrapturidae, including the genera Hemirhabdorhynchus, Aglyptorhynchus, 
380 Pseudoistriophorus, and Tetrapturus. The latter author also considered the genus Acestrus (an

381 istiophorid in Fierstine, 1972) as incertae sedis. Later, Fierstine and Monsch (2002) recovered

382 the five families of Fierstine (1972), but considered the genera Aglyptorhynchus,

383 Cylindracanthus and Hemirhabdorhynchus as unsolved. The taxonomic status of

384 Cylindracanthus was discussed by Parris and Grandstaff (2001) who suggested affinities with

385 Acipenseriformes instead to Xiphioids. Fierstine (2006) reviewed again the fossil record of

386 billfishes, considering a large set of different specimens. This author listed the families

387 Blochiidae, Palaeorhynchidae, Xiphiidae and Istiophoridae, and the family Hemingwayidae

388 (Sytchevskaya and Prokofiev, 2002). In addition, the former family 'Xiphiorhynchidae' (sensu

389 Fierstine, 1972) was re-ranked to subfamily level (Xiphiorhynchinae), and included within the

390 Xiphiidae. After, Fierstine and Weems (2009) distinguished Aglyptorhynchus from all other

391 Palaeorhynchidae, erecting a new subfamily, Aglyptorhinchinae.

392 Phylogenetic analysis - The datamatrix of Fierstine and Monsch (2002) with the

393 modifications introduced here, was first tested with Traditional Search (Wagner; 1,000

394 replicates; 1,000 trees to save per replication), recovering nine most parsimonious cladograms.

395 Acanthocybium solandri was selected as the outgroup. Strict consensus cladogram returned a

396 polytomy between Loancorhynchus catrillancai, Xiphias gladius and Blochius spp. After, IterPcr

397 script (Pol and Escapa, 2009) was used for identifying 'Blochius' moorheadi and

398 Xiphiorhynchus as unstable taxa. Thus, 'Blochius' moorheadi was subsequently pruned, while

399 Xiphiorhynchus was kept because it phylogenetic placement is relevant for assessing any

400 eventual relationship to Loancorhynchus catrillancai. As a result, Xiphias gladius was obtained

401 as the sister taxon of a polytomic group conformed by Blochius spp. + Loancorhynchus

402 catrillancai. Further pruning of non-xiphioid taxa Cylindracanthus and Hemirhabdorhynchus, 
403 returned the same relationships betweeen Xiphias and Blochius spp. + Loancorhynchus

404 catrillancai, the latter in polytomy. Pseudotetrapturus was later pruned from the previous

405 datamatrix version, and tested with Implied Weighting, obtaining Loancorhynchus catrillancai

406 as the sister taxon of Blochius. As obtained synapomporphies, the presence of dorsal longitudinal

407 ridges on the rostrum (Char. 7) groups Loancorhynchus catrillancai with the Blochiidae, while

408 the presence of villiform teeth in the rostrum and dentary (Char. 27) segregates Loancorhynchus

409 catrillancai from Blochius longirostris and Blochius macropterus. The topology of this

410 cladogram is shown in Fig. 7.

411 In addition, the phylogenetic analysis returned Xiphiorhynchus as a basal lineage with

412 respect to Xiphias. Previous to this research, Xiphiorhynchus was obtained as the sister taxon of

413 Xiphias (Fierstine and Monsch, 2002). Another novel result is the obtention of Hemingwaya as

414 the sister taxon of Palaeorhynchus + Homorhynchus.

415 Paleobiogeography_Previous to this research, the known records of Blochiidae were

416 restricted to the Middle Eocene of Monte Bolca, Italy. Loancorhynchus catrillancai represents

417 the first occurrence of a blochiid in the southern hemisphere, and the fourth record of a

418 Paleogene xiphioid in the Weddellian Province, adding to cf. Xiphiorhynchus from the Eocene of

419 Marambio (=Seymour) Island, Antarctica (Cione et al., 2001), Aglyptorynchus hakataramea,

420 from the late Oligocene of New Zealand (Gottfried et al., 2013), and the still undescribed GS

42113924 skull from the Eocene of Otago, New Zealand (Campbell et al., 2013). This sparse record

422 reveals a diversity of Paleogene xiphioids in the southern hemisphere, restricted to the families

423 Xiphiorhynchidae, Palaeorhynchidae, and now Blochiidae.

424

425 CONCLUSIONS 
426 Loancorhynchus catrillancai represents the unique Middle Eocene xiphioid known to date in the

427 southeastern Pacific. Its first available elements (rostrum and dentaries) were initially considered

428 as an indeterminate xiphiorhynchine (Friedman and Otero, 2009), while its stratigraphic

429 provenance remained dubious since 1935, when this specimen was recovered. New preparation

430 revealed basal features found among blochiids, xiphiorhynchines and hemingwayids. Also,

431 derived traits exclusively known in Neogene xiphiines were found in SGO.PV.6634. Based on

432 these facts, this research reassesses the taxonomical determination of SGO.PV.6634, being now

433 identified as a new genus and species, Loancorhynchus catrillancai. This new genus and species

434 represents the first record of the clade Blochiidae in the southern hemisphere. The new

435 occurrence of a Middle Eocene swordfish now in the southeastern Pacific, helps to fill the

436 Eocene-Middle Miocene gap in the xiphioid fossil record. It also represents the fourth record of a

437 Paleogene billfish in the Southern Hemisphere, showing that this group already reached a wide

438 distribution along the Southern Hemisphere previous to the Neogene, with Eocene records

439 known in New Zealand (Gottfried et al., 2013; Campbell et al., 2013), Antarctica (Cione et al.,

440 2001) and the new record here presented, now in South America.

441

442 Acknowledgments

443 Special thanks are due to H. Fierstine (California Polytechnic State University) who provided

444 valuable literature during early stages of this research. Thanks also to M. Friedman (University

445 of Oxford) for his contribution in the preliminary study of SGO.PV.6634. A.M. Prokofiev (A.N.

446 Severtsov's Institute of Ecology and Evolution, Russian Academy of Sciences) is also thanked

447 by valuable literature provided. K. Monsch (Naturalis Biodiversity Center, Netherlands) is

448 acknowledged for the revision of a early version of the manuscript. M. Gottfried (Geological 
449 Sciences and Museum, Michigan State University, USA), P. Brito (Universidade do Estado do 450 Rio de Janeiro, Brasil), D. Parris (New Jersey State Museum, USA) and G. Piñeiro (Universidad 451 de la República, Uruguay) are especially thanked for their reviews and all the comments that 452 improved this paper. R.E. Fordyce (Otago University, Dunedin, New Zealand) is acknowledged 453 for allowing access to the holotype of Aglyptorhynchus hakataramea during 2013.

Institutional Abbreviations

456 GS, Geological Survey, GNS Science, Lower Hutt, Wellington, New Zealand.

457 SGO.PI, Paleontología de Invertebrados, Museo Nacional de Historia Natural, Santiago, Chile. 458 SGO.PV, Paleontología de Vertebrados, Museo Nacional de Historia Natural, Santiago, Chile.

460 New Species Registration

461 The following information was supplied regarding the registration of newly described 462 taxa:

463 Genus name: LSID:urn:lsid:zoobank.org:act:FA566753-31D4-45B5-9E7A-03F8C7526E7D

464 Species name: LSID: urn:lsid:zoobank.org:act:8FFA9EE9-A81B-4468-9FBA-9D6C306D86C8

465 Publication: LSID:urn:Isid:zoobank.org:pub:ED22325A-7C78-469A-9985-365C31064652

466

467 REFERENCES

468 Bleeker PE. 1859. Enumeratio Specierum Piscium hueusque in Archipelago Indico

469 observatarum. Verhandelingen der Naturkundige Vereeninging in Nederlandsch Indië

$470 \quad 6: 1-276$. 
471 Campbell H, Beu A, Crampton J, Kennedy L, Terezow M. 2013. A Photographic Guide to 472 Fossils of New Zealand. New Holland Publishers, New Zealand. 144 p.

\section{Castro N, Salazar C, Otero RA, Stinnesbeck W, Escare A. 2016. V Simposio de}

474 Paleontología en Chile, Libro de Resúmenes, p. 26-28. November 7-11, 2016. Concepción.

475 Cecioni G. 1968. El Terciario de Chile. Zona central. Sociedad Geológica de Chile. Editorial 476 Andrés Bello, Santiago, Chile. 280 p.

477 Charrier R, Pinto L, Rodríguez MP. 2007. Tectonostratigraphic evolution of the Andean Orogen in Chile. In: Moreno T, Gibbons W, eds., The Geology of Chile, The Geological Society, London, 21-114.

Cione AL, Reguero MA, Elliot DH. 2001. A large osteichthyan vertebra from the Eocene of Antarctica. Neues Jahrbuch Fur Geologie Und Palaontologie Monatshefte 9:543-552.

Fierstine H. 1972. The paleontology of billfish — The state of the art. In: Shomura R, Williams F, eds., Contributed papers, Proceeding of the International Billfish Symposium, KailuaKona, Hawaii, 9-12 August, 1972, 34-44.

Fierstine H. 1990. A paleontological review of three billfish families (Istiophoridae, Xiphiidae, and Xiphiorhynchidae). In: stroud RH, ed. Planning the future of billfishes. Part 2. contributed papers. Proceedings of the Second International Billfish Symposium, p. 11-19. Kailua-Kona, Hawaii, August 1-5, 1988.

Fierstine H. 2006. Fossil history of billfishes (Xiphioidei). Bulletin of Marine Science 79:433-453.

491 Fierstine HL, Monsch KA. 2002. Redescription and phylogenetic relationships of the Family 492 Blochiidae (Perciformes: Scombroidei), Middle Eocene, Monte Bolca, Italy. Miscellanea 
493 Paleontologia, Studi e Richerche sui Giacimenti Terziari de Bolca, Museo Civico di Storia $494 \quad$ Naturale di Verona 9:121-163.

495 Fierstine, HL, Voigt NL. 1996. Use of rostral characters for identifying adult billfishes

496 (Teleostei: Perciformes: Istiophoridae and Xiphiidae). Copeia 1996:148-161.

497 Fierstine HL, Weems RE, 2009. Paleontology of the Oligocene Ashley and Chamber Bridge

498 formations of South Carolina, 4:analysis and new records of billfishes (Perciformes:

499 Xiphioidei). Palaeoichthyologica 11:43-88.

500 Friedman M, Otero RA. 2009. First fossil billfish (Perciformes: Xiphiidae) from central Chile.

501 Congreso Geológico Chileno XII, Symposium 10, Abstract 29, p. 1-4. Santiago, November $502 \quad 22-26,2009$.

503 García F. 1968. Estratigrafía del Terciario de Chile central. In: Cecioni G, ed. El Terciario de 504 Chile. Zona central. Sociedad Geológica de Chile. Editorial Andrés Bello, Santiago, Chile, p. $505 \quad 25-57$.

506 Goloboff PA, Farris JS, Nixon KC. 2008. TNT, a free program for phylogenetic analysis.

$507 \quad$ Cladistics 24:774-786.

508 Gosline WA. 1968. The suborders of Perciform Fishes. Proceedings of the United States 509 National Museum 126:1-78.

510 Gottfried M, Fordyce RE, Rust S. 2013. A new billfish (Perciformes, Xiphioidei) from the late 511 Oligocene of New Zealand. Journal of Vertebrate Paleontology 32:27-34.

512 Grandstaff BS, Pellegrini RA, Parris DC, Clements D. 2017. Thin section microscopy of the 513 fossil fish Cylindracanthus. Proceedings of the South Dakota Academy of Science $514 \quad 96 ; 130-143$. 
515 Gregory WK, Conrad GM. 1937. The comparative osteology of the swordfish (Xiphias) and

516 the sailfish (Istiophorus). American Museum Novitates 952:1-28.

517 Johnson GD, Patterson C. 1993. Percomorph phylogeny: a survey of acanthomorphs and a new

518 proposal. Bulletin of Marine Science 52:554-626.

519 Johnson GD. 1986. Scombroid phylogeny: An alternative hypothesis. Bulletin of Marine

$520 \quad$ Science 39:1-41.

521 Le Roux JP, Nielsen SN, Henríquez A. 2008. Depositional environment of Stelloglyphus

522 llicoensis isp. nov.: a new radial trace fossil from the Neogene Ranquil Formation, south-

523 central Chile. Revista Geológica de Chile 35:307-319.

524 Long DJ. 1993. Late Miocene and Early Pliocene fish assemblages from the north central coast 525 of Chile. Tertiary Research 14:117-126.

526 Martínez-Pardo R. 1968a. Edad y paleoecología del "Piso de Millongue". In: Cecioni G, ed. El

527 Terciario de Chile. Zona central. Sociedad Geológica de Chile. Editorial Andrés Bello,

528 Santiago, Chile, p. 125-141.

529 Martínez-Pardo R. 1968b. Necesidad de una nueva comprensión de los esquemas estratigráfio

530 clásicos sobre el Terciario de Chile Central. In: Cecioni G, ed. El Terciario de Chile. Zona

531 central. Sociedad Geológica de Chile. Editorial Andrés Bello, Santiago, Chile, p. 95-103.

532 Monsch K, Bannikov AF. 2011. New taxonomic synopses and revision of the scombroid fishes

533 (Scombroidei, Perciformes), including billfishes, from the Cenozoic of territories of the

534 former USSR. Earth and Environmental Science Transactions of the Royal Society of

535 Edinburgh 102:253-300.

536 Mordojovic C. 1981. Sedimentary basins of the Chilean Pacific Basin. American Association of 537 Petroleum Geologists, Bulletin 12:63-82. 
538 Muizon C. de, DeVries TJ. 1985. Geology and Paleontology of late Cenozoic marine deposits

539 in the Sacaco area (Peru). Geologische Rundschau 74:547-563.

540 Muñoz-Cristi J. 1946. Estado actual del conocimiento sobre la geología de la provincia de

541 Arauco. Anales Facultad de Ciencias Físicas y Matemáticas, Universidad de Chile 3:30-63.

542 Muñoz-Cristi J. 1968. Contribución al conocimiento geológico de la región situada al sur de

543 Arauco y participación del material volcánico en los sedimentos eocenos. In: Cecioni G, ed.

544 El Terciario de Chile. Zona central. Sociedad Geológica de Chile. Editorial Andrés Bello,

545 Santiago, Chile, p. 63-93.

546 Nakamura I. 1985. an annotated and illustrated catalogue of marlins, sailfishes, spearfishes, and 547 swordfishes known to date. Fao Fisheries synopsis No. 125 5:1-65.

548 Otero RA. 2015. Síntesis preliminar del registro fósil de vertebrados en Faro Carranza (Región 549 del Maule) y su aporte al conocimiento geológico del área. XIV Congreso Geológico Chileno, 550 Libro de Actas, p. 708-711. La Serena, October 2015.

551 Parris DC, Grandstaff BS. 2001. Reassessment of the affinities of the extinct genus

552 Cylindracanthus (Osteichthyes). Proceedings of the South Dakota Academy of Science

$553 \quad 80: 161-172$.

554 Pol D, Escapa IH. 2009. Unstable taxa in cladistics analysis: identification and the assessment

555 of relevant characters. Cladistics 25:515-527.

556 Pyenson ND, Gutstein CS, Parham JF, Le Roux JP, Carreño-Chavarría C, Little H,

557 Metallo A, Rossi V, Valenzuela-Toro AM, Velez-Juarbe J, Santelli CM, Rubilar Rogers

558 D, Cozzuol MA, Suárez ME. 2014. Repeated mass strandings of Miocene marine mammals

559 from Atacama Region of Chile point to sudden death at sea. Proceedings of the Royal Society

$560 \quad$ B 281: 9 p. DOI: 10.1098/rspb.2013.3316 
561 Regan CT. 1909. On the anatomy and classification of the scombroid fishes. Annals and

$562 \quad$ Magazine of Natural History 8:66-75.

563 San Martín R. 1946. Los sedimentos del Cretáceo y Terciario de Faro Carranza y Constitución.

564 Memoria para optar al título de Profesor de Estado en Ciencias Biológicas y Químicas,

$565 \quad$ Universidad de Chile. 76 p.

566 Schultz O. 1987. Taxonomische Neugruppierung der Oberfamilie Xiphioidea (Pisces,

567 Osteichthyes). Annalen des Naturhistorischen Museums in Wien Serie A. für Mineralogie and

568 Petrographie, Geologie und Palaontologie, Anthropologie und Prahistories. 89:95-202.

569 Sernageomin, 2003. Mapa Geológico de Chile. Versión Digital. Servicio Nacional de Geología

570 y Minería (Chile), Publicación geológica digital № 4, Escala 1:1.000.000.

571 Suárez ME, Otero RA. 2008. Nuevos hallazgos de vertebrados marinos en el Campaniano-

572 Maastrichtiano de Loanco, VII Región. I Simposio Paleontología en Chile, November 2008.

573 Santiago, Actas 78-82.

574 Sytchevskaya EK, Prokofiev AM. 2002. First Findings of Xiphioidea (Perciformes) in the Late

575 Paleocene of Turkmenistan. Journal of Ichthyology 42: 227-237.

576 Tavera J. 1942. Contribucipon al estudio de la estratigrafía y paleontología del Terciario de

577 Arauco. Anales del Primer Congreso Panamericano de Ingeniería en Minas y Geología

578 (Santiago), Tomo 2, pp. 580-632.

579 Tavera J. 1987. Noticia sobre hallazgo de una extremidad de Pliosaurus chilensis Gay en la

$580 \quad$ localidad para la Formación Quiriquina de Faro Carranza (latitud $35^{\circ} 36^{\prime}$ ). Monografía del

581 Departamento de Geología, Universidad de Chile. 18 pp. 
582 Walsh AA. 2001. The Bahía Inglesa Formation Bonebed: Genesis and Palaeontology of a

583 Neogene Konzentrat Lagerstätte from north-central Chile. University of Portsmouth, Doctoral

584 Thesis, $440 \mathrm{p}$.

585 Zambrano P, Nielsen S, Stinensbeck W. 2014. Taxonomía y relaciones tafonómicas en los 586 nautiloideos paleógenos de Sudamérica. IV Simposio Paleontología en Chile. Universidad 587 Austral de Chile, Valdivia, Chile. Libro de Resúmenes, p. 69.

588 Zinsmeister W. 1979. Biogeographic significance of the Upper Mesozoic and early Tertiary 589 molluscan faunas of Seymour Island (Antarctic Peninsula) to the final break-up of

590 Gondwanaland. In: Gray J, Boucot AJ, eds., Historical Biogeography, Plate Tectonics and

591 the Changing Environment. Oregon State University Press, Eugene, Oregon, 349-355.

592 Zinsmeister W. 1982. Late Cretaceous-Early Tertiary Molluscan Biogeography of the Southern 593 Circum-Pacific Journal of Paleontology 56:84-102. 
596

597

598

599

600

601

602

603

604

605

606

607

608

609

610

611

612

613

614

615

616

617

618

\section{FIGURE CAPTIONS}

Figure 1: Locality and stratigraphy of SGO.PV.6634. (A) Map indicating the locality of Loanco, where SGO.PV.6634 was recovered. (B) Scheme of the transgressive-regressive deposits in the Arauco Basin, indicating the respective units. Modified from Charrier et al., 2007.

(C) Stratigraphic column of the best Paleogene outcrop currently available (2016) in the coast south of Loanco. The unit is larger, however, this is covered by recent sands and by tsunami deposits after February 27, 2010. Sediment attached to SGO.PV.6634 is coincident with the fossil-bearing level containing Aturia sp. and Imaizula araucana.

Figure 2: Skull elements of SGO.PV.6634, holotype of Loancorhynchus catrillancai gen. et sp. nov. (A) Estimated body outline (based in Fierstine and Monsch, 2002). (B) Detail of the available skull elements of SGO.PV.6634. (C) Dorsal view of the rostral elements (D) Fin rays, with detail of the proximal part of the first right ray. Anatomical abbreviations: ah, articular head; at, anterior tuberosity; dr, dorsal ridges; fr, frontal; ld, left dentary; lmx, left maxillary; lop, left operculum; pmx, premaxillary; pn?, prenasals?; rhy, right hyomandibular; rop, right operculum.

Figure 3: Loancorhynchus catrillancai gen. et sp. nov. SGO.PV.6634, holotype. Distribution of villiform teeth and canali. (A) posterior part of the rostrum in lateral view. (B) detail of the villiform teeth present in the posterior part of the right premaxillary. (C) Left dentary in left lateral view. (D) detail of the villiform teeth in the anterior part of the left dentary. (E) Ventral view of the anterior rostrum fragment. $(F, G)$ Detail of the internal paired canali in the rostrum. 
Figure 4: Loancorhynchus catrillancai gen. et sp. nov. SGO.PV.6634, holotype. Anatomy of

621 the rostrum. (A) Right view. (B) Line drawing interpretation of the anatomical elements. (C)

622 same elements in dorsal view. (D) Line drawing interpretation of the anatomical elements. (E)

623 anterior view of the anteriormost rostral fragment. (F) Scheme of the previous. Anatomical

624 abbreviations: deth, dermethmoid; Imx, left maxillary; lpm, left premaxillary; pln,

625 posterolateral notch; pn?, prenasals(?); rpm, right premaxillary; vt, villiform teeth.

626

627 Figure 5: Loancorhynchus catrillancai gen. et sp. nov. SGO.PV.6634, holotype. Skull

628 elements. (A) Right hyomandibular/metapterygoid.in lateral (external) view. (B) Posterior view.

629 (C) Anterior view. (D) Internal view. (E) Left frontal in dorsal view. (F) Same in ventral view.

630 (G) Right opercle and supraopercular in right lateral view. (H) Left opercle in left lateral view.

631 Anatomical abbreviations: fhy, facet for the hyomandibular; hyo, hyomandibular; mpt,

632 metapterygoid; opp, opercular process; or, orbit; pog, preopercular groove; ptf, pterotic facet;

633 riop, right interoperculum; rsop, right supraopercular; spf, sphenotic facet; vii, foramen for the

634 truncus hyoideomandibularis of the facial nerve (VII).

635

636 Figure 6: Loancorhynchus catrillancai gen. et sp. nov. SGO.PV.6634, holotype. Dentaries.

637 (A) Dentaries in ventral view. (B) Scheme of the previous. (C) Dentaries in occlusal view. (D)

638 Left dentary (the most complete) in left lateral view. (E) Scheme of the previous. Anatomical

639 abbreviations: Id, left dentary; os, occlusal surface; rd, right dentary; vt, villiform teeth.

640 
641 Figure 7: Cladogram of the Xiphioidei, including Loancorhynchus catrillancai gen. et sp.

642 nov. Cladogram is based on the phylogenetic analysis performed here (Single MPC; CI=0.750;

643 RI=0.600; Implied Weighting (K-=3); New Technology Search; Ratchet. Pruned taxa: 'Blochius'

644 moorheadi, Cylindracanthus, Hemirhabdorhynchus and Pseudotetrapturus luteus). Biochrons

645 are based on Fierstine (2006). Body outlines are based in Nakamura (1985). Skull schemes

646 based in Gregory and Conrad (1937) and Fierstine and Monsch (2002). Dorsal longitudinal

647 ridges on the rostrum (Char. 7) supports Loancorhynchus catrillancai within the Blochiidae.

648 Villiform teeth in the rostrum and dentary (Char. 27). separates L. catrillancai from Blochius

649 longirostris and Blochius macropterus.

650

651

652 


\section{Figure 1}

Locality and stratigraphy of SGO.PV.6634.

(A) Map indicating the locality of Loanco, where SGO.PV.6634 was recovered. (B) Scheme of the transgressive-regressive deposits in the Arauco Basin, indicating the respective units. Modified from Charrier et al., 2007. (C) Stratigraphic column of the best Paleogene outcrop currently available (2016) in the coast south of Loanco. The unit is larger, however, this is covered by recent sands and by tsunami deposits after February 27, 2010. Sediment attached to SGO.PV.6634 is coincident with the fossil-bearing level containing Aturia sp. and Imaizula araucana. 

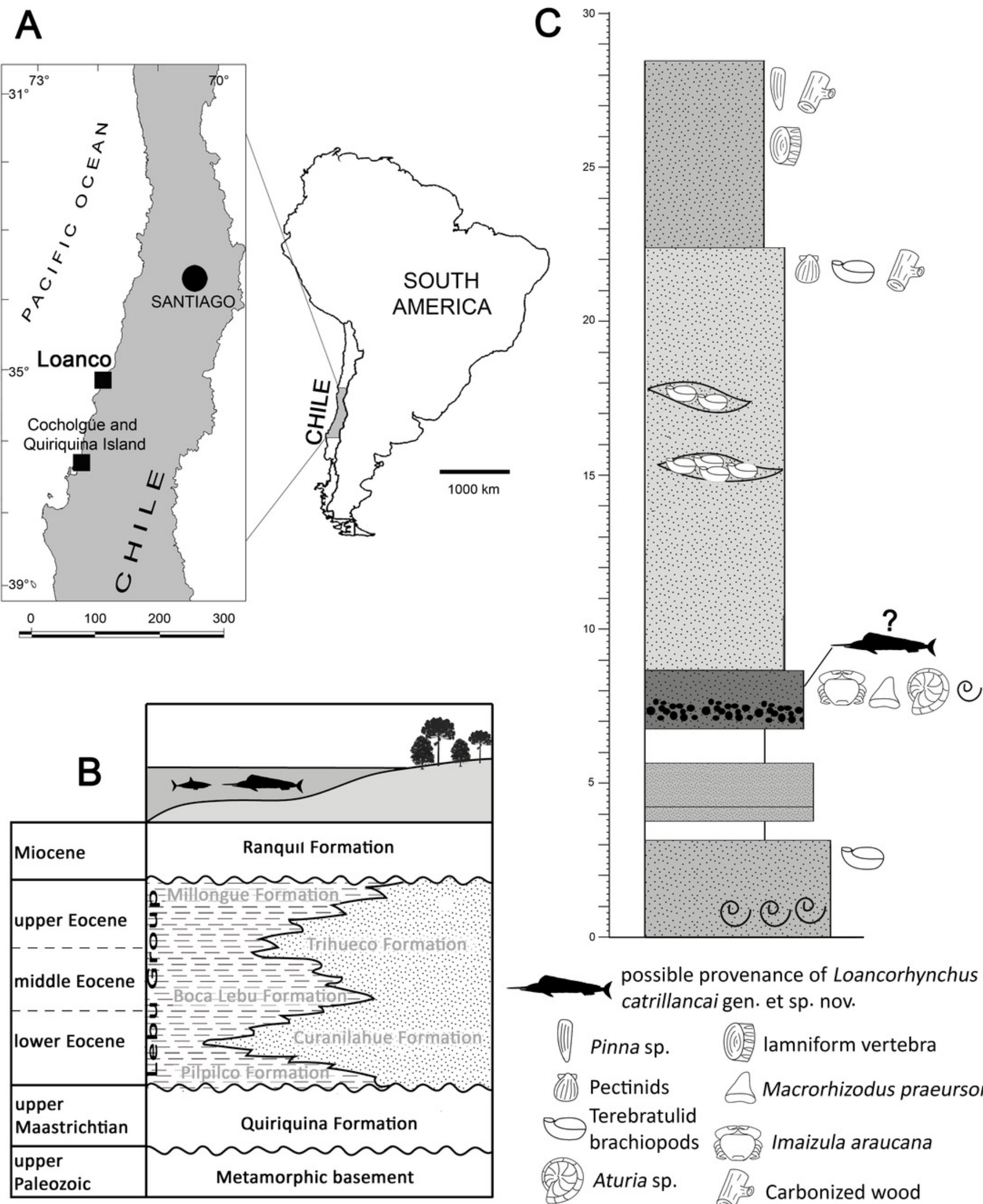

(II) Pinnasp. (6)

(III) Pectinids $\Leftrightarrow$ Macrorhizodus praeursor

Imaizula araucana

(2) Sturia sp. Serpulids




\section{Figure 2}

Skull elements of SGO.PV.6634, holotype of Loancorhynchus catrillancai gen. et sp. nov.

(A) Estimated body outline (based in Fierstine and Monsch, 2002). (B) Detail of the available skull elements of SGO.PV.6634. (C) Dorsal view of the rostral elements (D) Fin rays, with detail of the proximal part of the first right ray. Anatomical abbreviations: ah, articular head; at, anterior tuberosity; dr, dorsal ridges; fr, frontal; Id, left dentary; Imx, left maxillary; lop, left operculum; pmx, premaxillary; pn?, prenasals?; rhy, right hyomandibular; rop, right operculum.

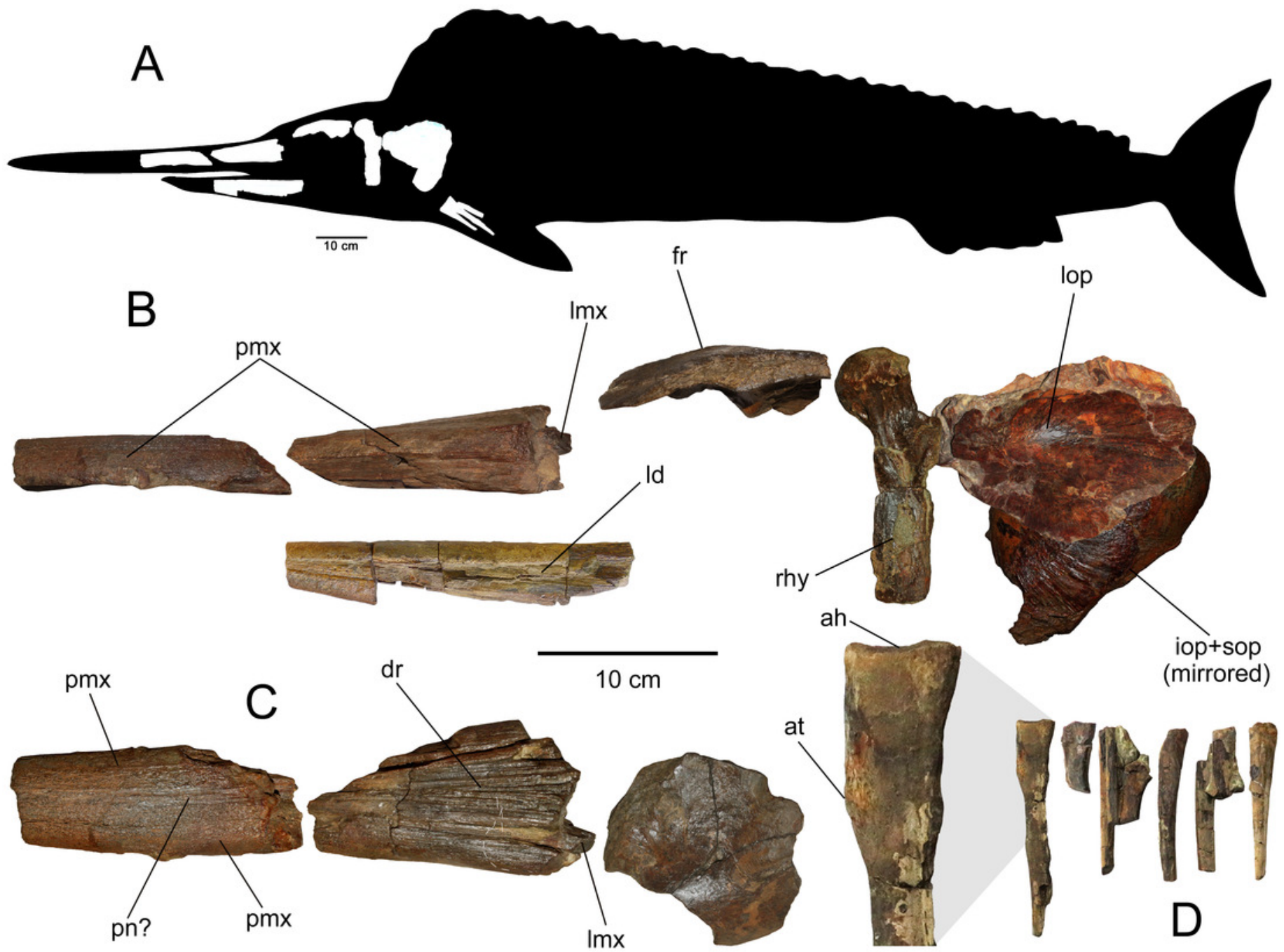




\section{Figure 3}

Loancorhynchus catrillancai gen. et sp. nov. SGO.PV.6634, holotype. Distribution of villiform teeth and canali.

(A) posterior part of the rostrum in lateral view. (B) detail of the villiform teeth present in the posterior part of the right maxillary. (C) Left dentary in left lateral view. (D) detail of the villiform teeth in the anterior part of the left dentary. (E) Ventral view of the anterior rostrum fragment. $(F, G)$ Detail of the internal paired canali in the rostrum.

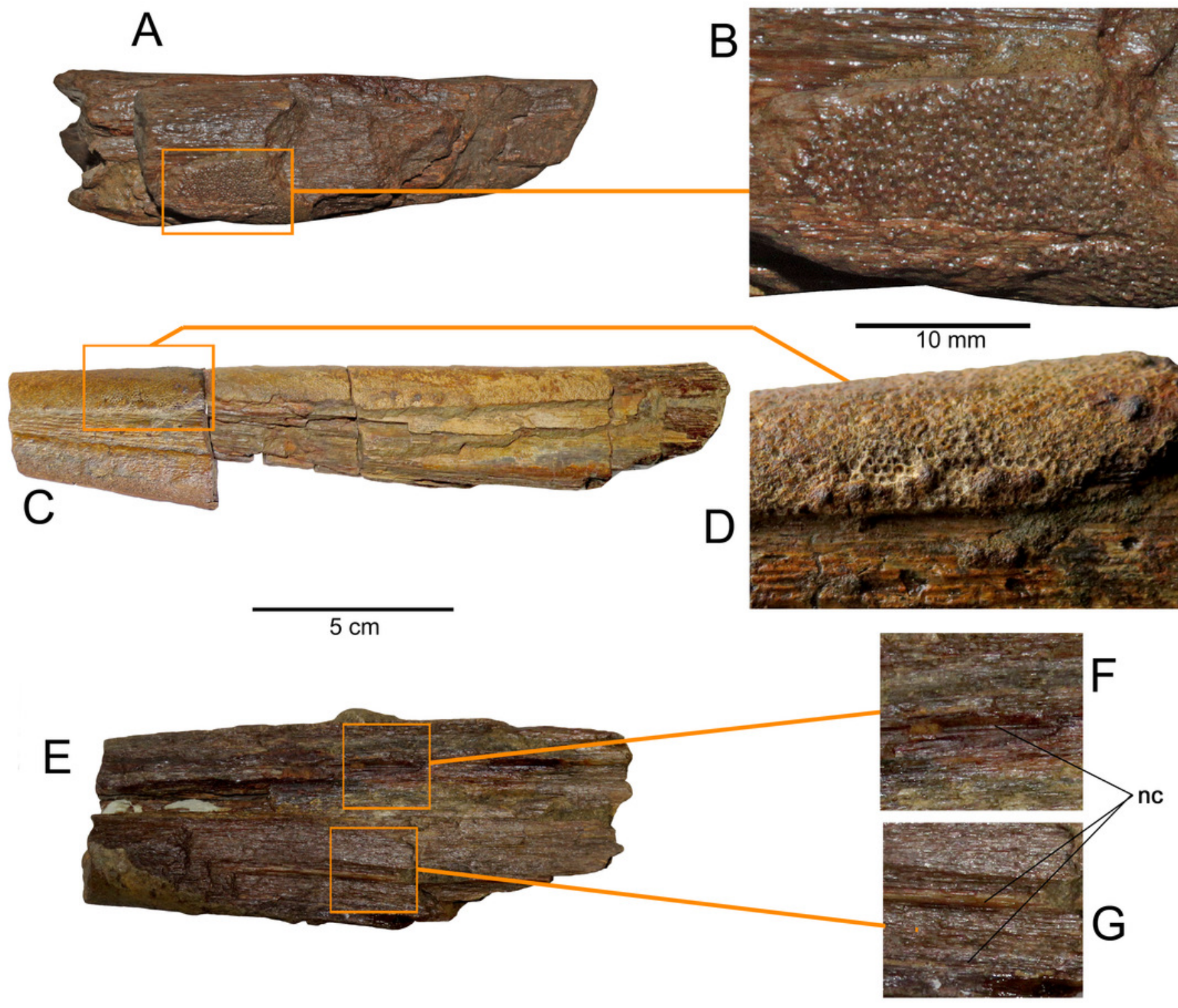




\section{Figure 4}

Loancorhynchus catrillancai gen. et sp. nov. SGO.PV.6634, holotype. Anatomy of the rostrum.

(A) Right view. (B) Line drawing interpretation of the anatomical elements. (C) same elements in dorsal view. (D) Line drawing interpretation of the anatomical elements. (E) anterior view of the anteriormost rostral fragment. (F) Scheme of the previous. Anatomical abbreviations: deth, dermethmoid; Imx, left maxillary; Ipm, left premaxillary; pln, posterolateral notch; pn?, prenasals(?); rpm, right premaxillary; vt, villiform teeth. 

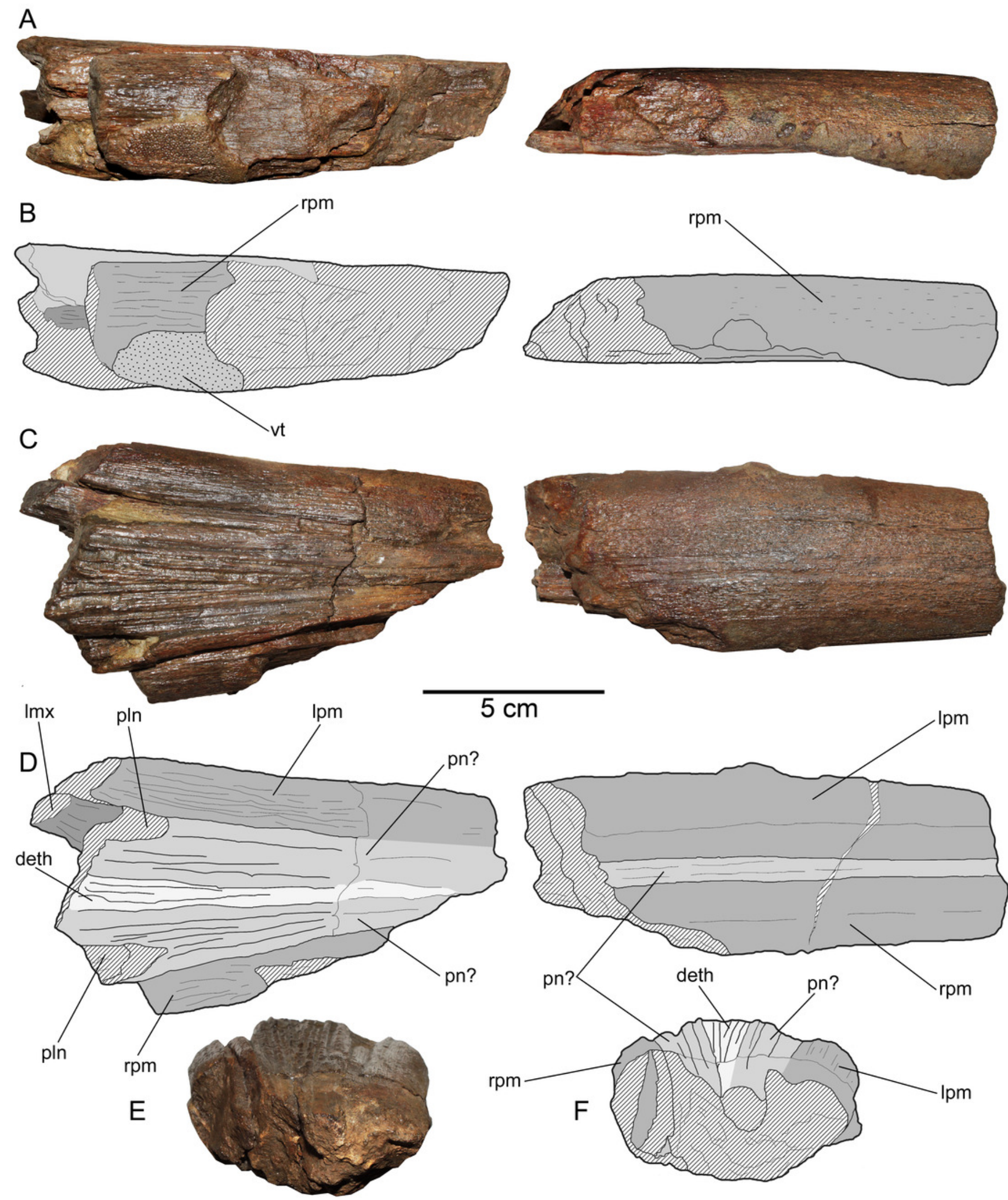


\section{Figure 5}

Loancorhynchus catrillancai gen. et sp. nov. SGO.PV.6634, holotype. Skull elements.

(A) Right hyomandibular/metapterygoid.in lateral (external) view. (B) Posterior view. (C) Anterior view. (D) Internal view. (E) Left frontal in dorsal view. (F) Same in ventral view. (G) Right opercle and supraopercular in right lateral view. (H) Left opercle in left lateral view. Anatomical abbreviations: fhy, facet for the hyomandibular; hyo, hyomandibular; mpt, metapterygoid; opp, opercular process; or, orbit; pog, preopercular groove; ptf, pterotic facet; riop, right interoperculum; rsop, right supraopercular; spf, sphenotic facet; vii, foramen for the truncus hyoideomandibularis of the facial nerve (VII). 


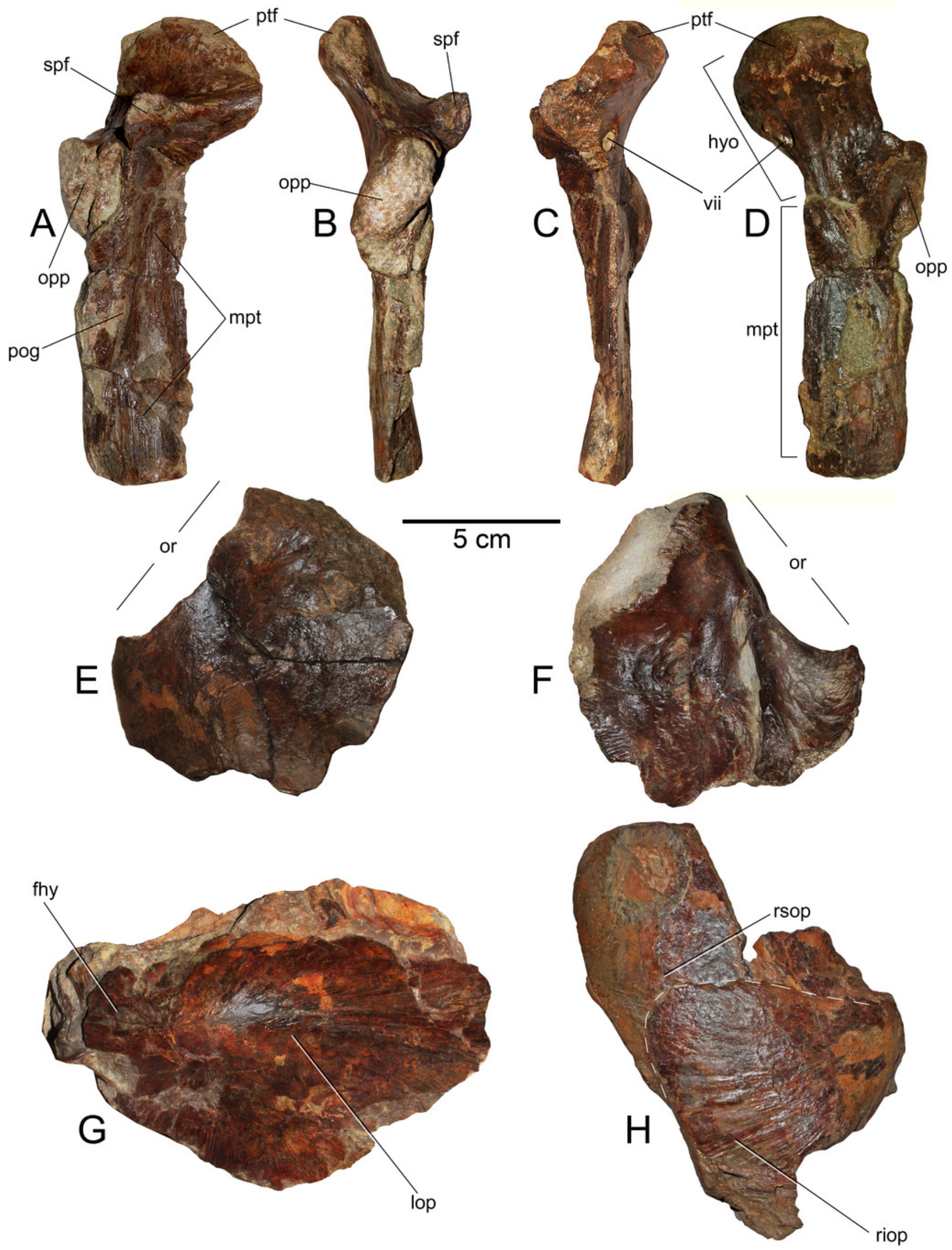


Figure 6

Loancorhynchus catrillancai gen. et sp. nov. SGO.PV.6634, holotype. Dentaries.

(A) Dentaries in ventral view. (B) Scheme of the previous. (C) Dentaries in occlusal view. (D) Left dentary (the most complete) in left lateral view. (E) Scheme of the previous.

Anatomical abbreviations: Id, left dentary; os, occlusal surface; rd, right dentary; vt, villiform teeth. 

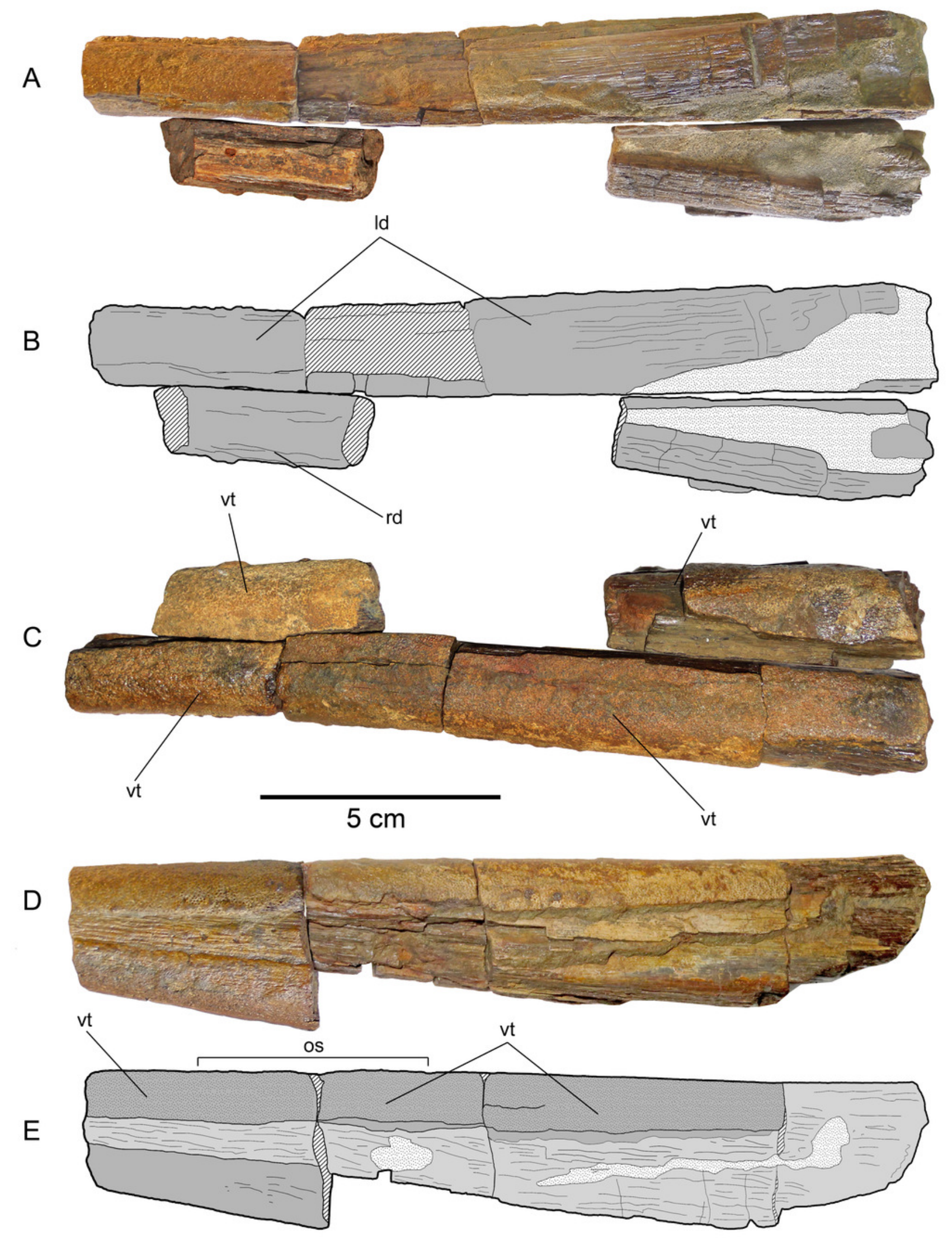


\section{Figure 7}

Cladogram of the Xiphioidei, including Loancorhynchus catrillancai gen. et sp. nov.

Cladogram is based on the phylogenetic analysis performed here (Single MPC; $\mathrm{Cl}=0.750$;

$\mathrm{RI}=0.600$; Implied Weighting (K-=3); New Technology Search; Ratchet. Pruned taxa:

'Blochius' moorheadi, Cylindracanthus, Hemirhabdorhynchus and Pseudotetrapturus luteus). Biochrons are based on Fierstine (2006). Body outlines are based in Nakamura (1985). Skull schemes based in Gregory and Conrad (1937) and Fierstine and Monsch (2002). Dorsal longitudinal ridges on the rostrum (Char. 7) supports Loancorhynchus catrillancai within the Blochidae. Villiform teeth in the rostrum and dentary (Char. 27). separates $L$. catrillancai from Blochius longirostris and Blochius macropterus.

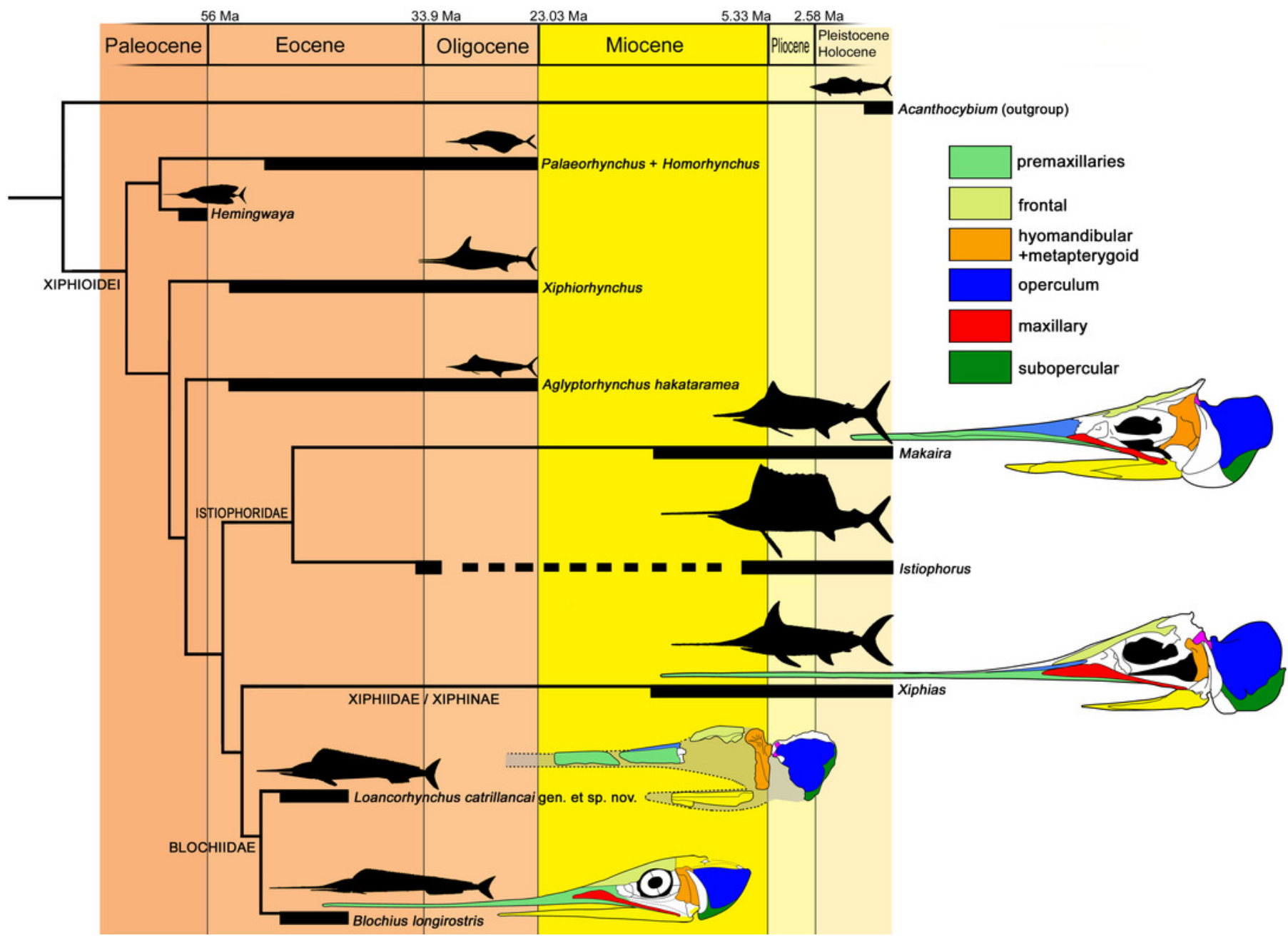

